Brazilian Journal

of Chemical

ISSN 0104-6632

Printed in Brazil

Engineering

\title{
DEVELOPMENT AND OPTIMIZATION OF A SINGLE-STEP CATION CHROMATOGRAPHIC WHEY PROTEIN FRACTIONATION PROCESS: EVALUATION AND COMPARISON OF SCALE-UP STRATEGIES
}

\author{
Umesh Ingle ${ }^{1,2 *}$ and Arvind Lali ${ }^{1}$
}

\author{
${ }^{1}$ DBT-ICT Centre for Energy Biosciences, Department of Chemical Engineering, \\ Institute of Chemical Technology (ICT), Matunga, Mumbai-400019, Maharashtra, \\ India \\ ${ }^{2}$ Currently at Praj Matrix R \& D Centre, Praj Industries Ltd., Urawade, Pune- \\ 412115, India. Ph: +91 20 66754000/4087, Fax: +912022922004
}

(Submitted: July 8, 2016; Revised: January 20, 2017; Accepted: May 30, 2017)

\begin{abstract}
This manuscript presents evaluation of various strategies used for the scale-up of chromatographic purification systems. Towards that end, the manuscript provides development and optimization of a single-step whey protein concentrate (WPC) fractionation process at lab scale on a $1.0 \times 19 \mathrm{~cm}$ column using UNOsphere S. Subsequently, scale-up of this newly developed process and conduction of trials at higher scale is also undertaken by applying various scale-up strategies. For these trials, this work categorized various scale-up factors into constant velocity $\left(\mathrm{C}_{\mathrm{v}}\right)$ and constant bed volume per hour $\left(\mathrm{C}_{\mathrm{BVH}}\right)$ scale-up methods. Scale-up trials in bigger diameter $(1.5 \mathrm{~cm}$ and $2.5 \mathrm{~cm})$ columns with height to diameter ratio (H/D) $=19$ and $<19$ were performed. The effects of changing flow velocity and H/D ratio due to the applied scale-up strategy were evaluated and compared with lab performance in terms of resolution vs. lower equivalent to theoretical plate (HETP) relationship. The $\mathrm{C}_{\mathrm{BVH}}$ method was found to be an efficient method for the scale-up of the developed whey protein resolution system. Also an equation for the prediction of resolution in a scaled column on the basis of a HETP-resolution correlation is presented. It is useful for the prediction of either resolution or bed height in scaled column of WPC or similar biomolecular purification systems.
\end{abstract}

Keywords: HETP, Cation exchanger, Whey Proteins Fractionation, Chromatography Scale-up.

\section{INTRODUCTION}

Scale-up of any chromatographic purification process is possible by establishing proper scale-up factors which reproduce the thermodynamic and hydrodynamic performance of bench level. However, selection of suitable scale-up factors and how they are involved in recreation or deviation of bench scale

*Correspondence: Umesh Ingle, E-mail: umesh.udctmumbai@gmail.com, umeshingle@praj.net 
separation performance is important. This is possible only by comparative study of the effect of different scale-up approaches for the scale-up of one specific chromatographic purification system. In the current work such a comparative evaluation is conducted by the case study of whey protein resolution. For this purpose a new single step chromatographic method for the resolution of whey protein concentrate (WPC) is developed in the current work.

Whey is the byproduct of the cheese making process. It is a dilute mixture of proteins, lactose, minerals and vitamins. Earlier, dilute whey was considered to be a waste product. However, nutritional and health benefits of the proteins present in whey have attracted a great deal of market interest in recent years. Whey contains about $63 \mathrm{~g} \mathrm{~L}^{-1}$ solids of which $50 \mathrm{~g} \mathrm{~L}^{-1}$ is lactose and $6 \mathrm{~g} \mathrm{~L}^{-1}$ are proteins (Doultani et al., 2004). Major proteins of whey include $\alpha$-lactalbumin (ALA), $\beta$-lactoglobulin (BLG), immunoglobulin (IgG), bovine serum albumin (BSA), and glycomacropeptide (GMP). Minor but valuable proteins in whey are lactoferrin (LF) and lactoperoxidase (LPO) due to their medicinal and nutritional benefits.

Various methods based on precipitation (Pearce, 1983), ultra-filtration with thermal aggregation (USA 5503864; USA 4485040), and chromatography (Hann et al., 1998; Gerberding and Byers, 1998) have been reported in the literature for the purification of proteins from dilute whey. Of these methods, the ultrafiltration membrane technique was primarily used for the concentration of dilute whey (Baldasso et al., 2011). However, selective separation by membrane techniques on the basis of size requires a large difference in molecular weight and would therefore be limited to separating only certain protein components of whey (Goodall et al., 2008). To overcome this limitation Kirstiansen et al. (1998) used a combination of chromatographic and membrane processes for the fractionation of BLG and ALA from whey. This approach was improved further through the work of Saufi and Fee (2011) by developing a hybrid cationic mixed matrix membrane (MMM) method for the recovery of LF from bovine whey. This method is limited to the isolation of LF and LPO from whey. Voswinkel and Kulozik, (2011) reported a membrane adsorption chromatographic method for the isolation of proteins from whey.

In the context of isolation of proteins from whey, the use of chromatographic methods is considered to be promising as they have the capability to fractionate whey into a number of proteins in a single step (Doultani et al., 2003). Fee and Chand (2006) have reported a method based on cation chromatography for the isolation of LF and LPO from the dilute whey. Santos et al. (2012) reported an anion exchange method for the isolation of BLG from whey concentrate. However, most of these reported chromatographic methods are either based on specialized separation media or multistep low purity processes or for the purification of only two proteins like LF and LPO (Faraji et al., 2015). Most importantly, reported whey protein isolation methods are of the multistep type, requiring the development of a single-step whey proteins isolation chromatography method for the detailed study of scale-up aspects.

It has been observed from the above literature that a single-step resolution of various proteins in whey is possible by exploiting various operating and design parameters of ion exchange chromatography. Therefore, the present work invested efforts in the resolution of proteins from a rich source of whey proteins called whey protein concentrate (WPC) to avoid multistep and cumbersome processing of dilute whey. The WPC contains $24-80 \%$ of mixed proteins. The crucial task in the development of a single-step chromatographic method from WPC is the resolution of ALA and BLG. Both these proteins are structurally similar with a difference in their isoelectric points; ALA is $14.0 \mathrm{kDa}$ in size ( $\mathrm{p} I=4.2-4.5)$ and BLG is an $18.3 \mathrm{kDa}$ molecule $(\mathrm{p} I=4.8-5.2)$. Therefore, a cation exchange chromatographic method is effective for the exploitation of the charge and size variation of these two proteins and other proteins in whey to achieve the objective of a single column resolution process. This resolution of ALA and BLG is also important for the evaluation and measurement of effectiveness of the strategy applied for the scale-up of lab developed processes.

Various reports based on the recreation of hydrodynamic conditions by changing column design and operating parameters are available for the scaleup of chromatographic purification systems (Jansson and Jonsson, 1989; Lightfoot, 1999; Moscariello et al., 2001; Levison et al., 1992; Wilhelm and Riba, 1989; Wankat and Koo, 1988; Shanagar, 2005). In most of these reports, the scale-up of a chromatographic column is achieved by increasing the column diameter while keeping the bed height, the sample concentration, and the ratio of gradient volume to column volume constant (Ishihara et al., 2007; Hagel et al., 2008). In this case the sample volume and the volumetric flowrates are increased by the factor $\left(D_{2} / D_{1}\right)^{2}$, depending on the scaled column dimensions, where $D_{1}$ is the bench scale diameter and $D_{2}$ is the scaled column 
diameter. One approach reported in the literature for chromatographic scale-up is the establishment of a HETP-velocity relationship at lab scale by performing experiments on different diameter columns and applying it for scale-up (Heuer et al., 1996; Rathore and Velayudhan, 2002; Mollerup et al., 2007). Another approach suggests scale-up by enlarging the height of scaled column with constant $\mathrm{H} / \mathrm{D}$ ratio. One thus has to make decisions with regard to the design of the H/D ratio for the successful scale up from lab to plant scale (Vorauer et al., 1992). A low $\mathrm{H} / \mathrm{D}$ ratio or scale-up just by increasing column diameter may result in an unacceptably low resolution due to an improper flow distribution or lower number of equilibrium stages. Also a substantially lower H/D ratio than lab scale reduces the supporting force that keeps the particles in place as a smaller number of particles are supported by the column wall. However, a higher H/D ratio than lab scale cannot always maximize peak separation; moreover, it may lead to band spreading and increase of peak width, which reduces separation performance and increases overall run time and mobile phase consumption. Due to an increased H/D ratio at higher scale, the bottom of the column feels the high pressure drop, as well as weight of the filled adsorbent bed itself.

However, in the open literature, limited information is available on the contribution of $\mathrm{H} / \mathrm{D}$ or other selected scale-up factors in reproduction or deviation of separation performance of scaled column than bench set up. Apparently, the literature lacks systematic comparison of the effect of scale-up strategy, the H/D ratio and other factors are involved in the reproduction of lab level separation performance. Such a comparison is possible only when all the reported scale-up strategies are applied for the scaleup of one particular purification system. To address the above mentioned gaps, the current work first involves development of a lab scale chromatographic method for the separation of proteins in whey, then conduction of scale-up trials by applying various scale-up strategies to study the impact of the scale-up factors involved on reproduction of purification performance. In the current work this comparison is performed by the scaling of the chromatographic separation of proteins in WPC.

To attend all the issues, the present study categorized the scale-up factors into two distinct classes: (i) constant velocity, $\mathrm{C}_{\mathrm{V}}$ and (ii) constant bed volume per hour, $\mathrm{C}_{\mathrm{BVH}}$ (Charm and Matteo, 1971). Both these methods are applied for the scale-up of the developed lab scale whey protein resolution process. The effect of the scale-up factors involved is studied with a HETP-velocity relationship and by resolution of ALA and BLG. The correlation for the prediction of resolution based on the selected scale-up factors is also presented. The correlation is useful for the prediction of either resolution or bed height of the scaled column for whey protein or similar purification systems depending on the operating and design parameters of the intended scaled system.

\section{MATERIALS AND METHODS}

\section{Adsorbents, Columns, Equipment and Chemicals}

The strong cation exchange matrix, UNOsphere S, was a gift sample from Biorad Laboratories Ltd., USA. The detailed properties and characteristics of the UNOspher S matrix are shown in Table 1.

Bio-Rad Econo glass columns of size $1.0 \times 30 \mathrm{~cm}$, $1.5 \mathrm{~cm} \times 20 \mathrm{~cm}, 1.5 \mathrm{~cm} \times 30 \mathrm{~cm}, 2.5 \mathrm{~cm} \times 5.0 \mathrm{~cm}$ and $2.5 \mathrm{~cm} \times 50 \mathrm{~cm}$ with respective size adaptors for the conduction of lab and scale-up experiments were a gift from Bio-Rad Laboratories Ltd.

Experiments were performed using the Biologic Duo flow Path Finder preparative chromatography system of Biorad Laboratories Ltd., USA.

Table 1. Properties and characteristics of UNOsphere S.

\begin{tabular}{lc}
\hline Matrix Property & UNOsphere S \\
\hline Type of ion exchanger & Strong cation \\
Functional group & $\mathrm{SO}_{3}^{-}$ \\
Total ionic Capacity $(\mu \mathrm{eq} / \mathrm{mL})$ & 120 \\
Shipping counter ion & $\mathrm{Na}^{+}$ \\
Mean particle size $(\mu \mathrm{m})$ & 80 \\
Mean pore size $(\AA)$ & 1000 \\
pH stability & $2-14$ \\
Density $(\mathrm{kg} / \mathrm{L})$ & $\mathrm{Nd}$ \\
Regeneration & $70 \%$ ethanol or $1-2 \mathrm{M} \mathrm{NaCl}$ \\
\hline
\end{tabular}


Tris hydrochloride, i.e, tris(hydroxymethyl) aminomethane, and sodium acetate buffer were purchased from Sigma, India. Sodium chloride and sodium hydroxide were purchased from Merck, India. The Milli-Q water required for the preparation of buffer was produced in the lab by a water purification system of Millipore India Ltd.

\section{Whey Protein Concentrate (WPC) Sample}

Whey protein concentrate (WPC) powder (protein content $80 \%$ ) was purchased from Dynamix Dairy industries Ltd., India. Major proteins present in WPC include $\alpha$-lactalbumin (ALA) and b-lactoglobulin (BLG), with commercially important lactoferrin (LF) and lactoperoxidase (LPO). The content of various proteins of WPC with their properties are shown in Table 2.

Loading samples for the resolution experiments were prepared by dissolving a weighed amount of WPC powder in $25 \mathrm{mM}$ sodium acetate buffer of $\mathrm{pH}$ 3.2 to make a solution of $10 \mathrm{mg} \cdot \mathrm{mL}^{-1}$ of total protein concentration.

\section{Determination of Electrophoretic Purity}

The purity of proteins separated by chromatography was analyzed by sodium dodecyl sulphate $10 \%$ polyacrylamide gel electrophoresis (SDS-PAGE) as described by Laemmli (1970). Equal amounts of proteins were applied under non-reducing conditions. The gel was stained with silver and coomassie staining and documented using a gel imaging and documentation system (Versadoc, Bio-Rad).

\section{Operating Conditions}

Equilibration buffer: The equilibration phase was prepared by dissolving $25 \mathrm{mM}$ of sodium acetate in Milli-Q water to which acetic acid was added to attain a $\mathrm{pH}$ of 3.2 .

Elution buffer I (Elu-I): This was prepared by dissolving $25 \mathrm{mM}$ of sodium acetate in Milli-Q water with addition of $1.0 \mathrm{M} \mathrm{NaCl}$, then the $\mathrm{pH}$ was adjusted to 3.2 .

Elution buffer II (Elu-II): Another elution buffer was prepared by dissolving $25 \mathrm{mM}$ tris with addition of $1.0 \mathrm{M}$ of $\mathrm{NaCl}$ in Milli-Q water; then the $\mathrm{pH}$ was adjusted to 8.0 by the addition of concentrated hydrochloric acid.

Linear gradient elution: In this mode, the elution strength of the mobile phase was linearly modified with time. It was achieved by mixing the two mobile phases in respective proportions by adjusting their flow rates. In this study, a linear gradient was applied by changing the Elu-I content from $0-100 \%$ in the equilibration buffer. This was done by pumping equilibration buffer using pump A and Elu-I by using pump B of the Biologic Duo flow system. The flow rates of both of these pumps were programmed using the system software to produce the desired change of Elu-I percentage with time in the final mixed composition going to the column at a desired flow rate.

Step Gradient elution: Elution strength (\% Elu-I) in the elution phase corresponding to the elution peaks obtained in linear gradient conditions was determined. Depending on the values from the linear gradient run, new buffer compositions of estimated elution strength, $\mathrm{pH}$ and conductivity conditions were prepared.

Various elution phases such as $0.5 \mathrm{M} \mathrm{NaCl}$ in $25 \mathrm{mM}$ sodium acetate, $\mathrm{pH} 3.2,0.75 \mathrm{M} \mathrm{NaCl}$ in $25 \mathrm{mM}$ sodium acetate, $\mathrm{pH} 3.2,1.0 \mathrm{M} \mathrm{NaCl}$ in $25 \mathrm{mM}$ sodium acetate, $\mathrm{pH} 5.0,1 \mathrm{M} \mathrm{NaCl}$ in $25 \mathrm{mM}$ Tris- $\mathrm{HCl}, \mathrm{pH} 8.0$, were prepared for step gradient elution.

\section{Resolution of WPC in Column Mode: Whey Fractionation Method}

Experiments to develop the lab scale whey protein resolution process were carried out by packing adsorbent up to $19 \mathrm{~cm}$ height in a $1.0 \mathrm{~cm} \times 30 \mathrm{~cm}$ glass Econo column. The quality of packing was checked by the distribution of an acetone pulse at the column outlet. Uniform binding conditions were developed by equilibrating the column with three bed volumes

Table 2. Properties of proteins present in the whey concentrate.

\begin{tabular}{lcc}
\hline Proteins & Molecular weight (kDa) & Isoelectric point (p) \\
\hline alpha-lactalbumin (ALA) & 14.0 & $4.7-5.1$ \\
Beta-Lactoglobulin (BLG) & 18.3 & $5.2-5.4$ \\
Immunoglobulin (IgG) & 150.0 & $5.8-7.3$ \\
Bovine serum albumin (BSA) & 66.0 & $4.9-5.1$ \\
Glycomacropeptide (GMP) & $4-6.7$ & ---- \\
Lactoferrin (LF) & 80.0 & 9.6 \\
Lactoperoxidase (LPO) & 77.0 & 8.0 \\
\hline
\end{tabular}




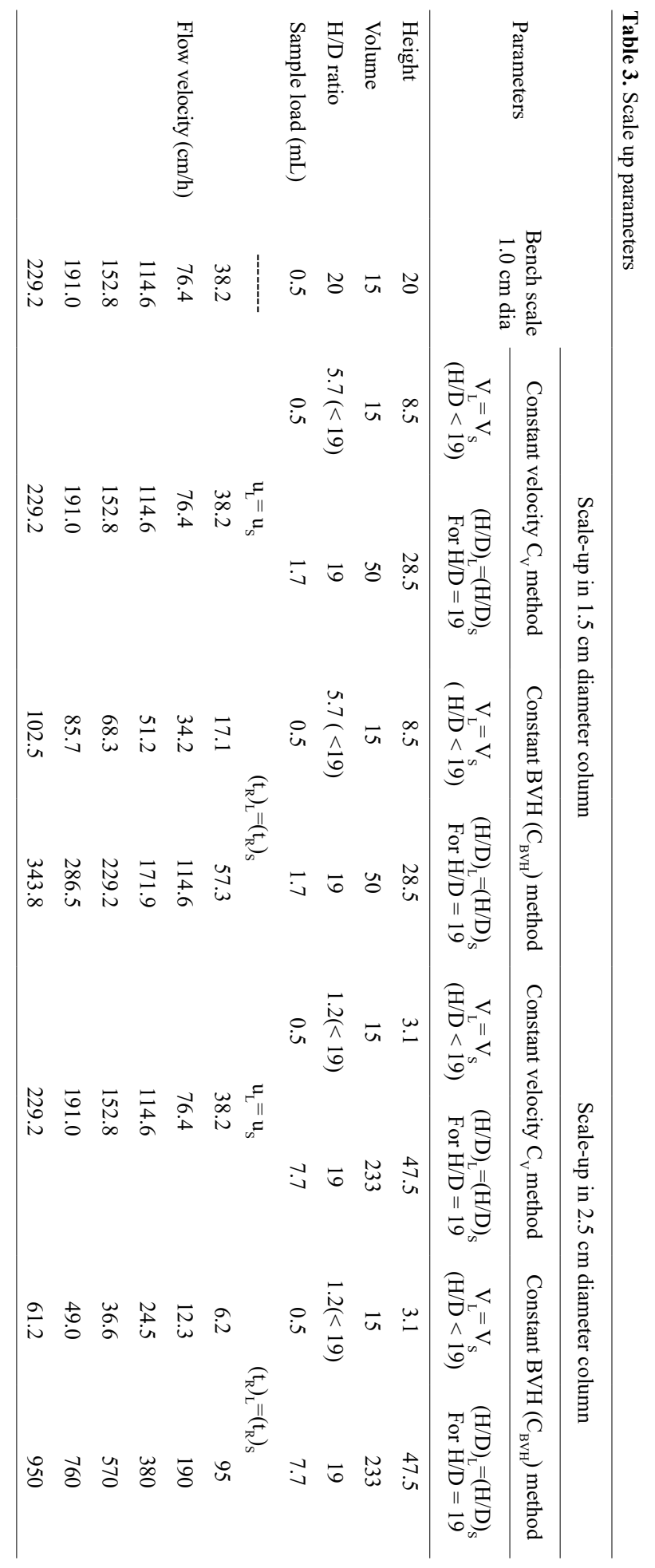


of equilibration buffer. After that, a WPC sample of volume $4.0 \mathrm{ml}$ was loaded on the column. Washing was done with a 2.0 bed volume (BV) of equilibration buffer. For the distinct identification of the effect of scale-up strategy, elution optimization was devised to obtain the resolution of two proteins (peaks) in the same elution step. To achieve this, various elution strategies were applied. Initially, linear gradient elution from 0 to $100 \%$ between equilibration buffer and Elu-I was applied to obtain the desired resolution. This linear gradient elution was then converted into a number of elution steps of $\mathrm{NaCl}$ concentration. Regeneration was done by using 2.0 BV of buffer Elu-II. The flow conditions were varied in the range of 38 to $380 \mathrm{~cm}$ $\mathrm{h}^{-1}$ to study the effect of flow rate on the established resolution.

\section{Scale-up Studies}

The effect of scale-up strategy on purification performance was accounted for by the variation of resolution coefficient of two proteins with similar characteristics established at lab level.

In scale up trials thermodynamic conditions for binding were kept identical by following the optimized lab scale WPC resolution process. The parameters reported in Table 3 corresponding to $\mathrm{C}_{\mathrm{V}}$ and $\mathrm{C}_{\mathrm{BVH}}$ strategies were used for the scale up of lab process. The effect of aspect ratio was incorporated by conducting scale up experiments in two ways: (i) trial runs by keeping the resin volume in the lab and scaled column constant, i.e. $\mathrm{H} / \mathrm{D}<19$ and (ii) trial runs conducted with constant H/D ratio $\left[(\mathrm{H} / \mathrm{D})_{\mathrm{L}}=(\mathrm{H} / \mathrm{D})_{\mathrm{S}}\right]$

The scale-up factor for loading was determined using Equation (1) for all the scale-up trials (Wankat and Koo, 1998).

$$
\frac{V_{i n j}}{V_{c o l}}=\text { Cons } \tan t
$$

where $\mathrm{V}_{\text {inj }}=$ sample volume loaded on the column, $\mathrm{V}_{\text {col }}$ is the packed column volume. Other scale up factors were determined as per the $\mathrm{C}_{\mathrm{BVH}}$ or $\mathrm{C}_{\mathrm{V}}$ strategy, as reported in Table 3. Numerous experiments were performed in larger 1.5 and $2.5 \mathrm{~cm}$ diameter columns by maintaining operating conditions according to the scale-up factors of the $\mathrm{C}_{\mathrm{BVH}}$ and $\mathrm{C}_{\mathrm{V}}$ strategy.

\section{RESULTS AND DISCUSSION}

\section{Resolution of Whey Proteins by Cation Exchange Chromatography}

The design of chromatographic processes for purification of biomolecules mainly involves: (a) selection of the mode of interaction based on the nature of the separation problem and (b) optimization of operating conditions for the desired purification. The selection of mode of interaction depends on the properties of the molecule of interest and interfering components. WPC is a mixture of different size proteins having isoelectric points $(\mathrm{p} I$ 's) in the range of 4.2 to 9.5 , as given in Table 2 . This charge and size variation of whey proteins was possible to exploit by employing a macroporous cation exchange chromatography resin to achieve the objective of a single column separation process for scale up studies. To attain the process requirements, the following conditions are required: an adsorbent of high binding capacity, strong binding strength towards WPC proteins and superior intraparticle diffusion characteristics. UNOsphere $\mathrm{S}$ media provides a loading capacity of $100 \mathrm{mg}(\mathrm{mL}$ resin $)^{-1}$ and strong binding strength with respect to lysozyme. Also, it was found that UNOsphere S showed superior intraparticle transport characteristics, having a normalized diffusivity (effective diffusion/ molecular diffusion) of 1.45 for lysozyme on the Hunter and Carta (2000) evaluation scale. In addition, Ingle and Lali (2017) reported that UNOsphere S adsorbent showed high pore permeability and superior pore area accessibility for $66 \mathrm{kDa}$ size proteins. Therefore, cationic UNOSphere $\mathrm{S}$ was selected for the purification. Considering the $\mathrm{p} I$ range of proteins in whey, $25 \mathrm{mM}$ sodium acetate of $\mathrm{pH} 3.2$ was designed as an equilibration phase for establishment of complete binding conditions.

Optimization of the operating and elution conditions was then carried out for the resolution of two proteins with similar characteristics in the same elution step. Initially for the determination of elution strength of the bound proteins of WPC and for their resolution, a linear elution gradient (changing the Elu-I concentration from $0-100 \%$ ) of 20 bed volumes (BV) was applied to the cation column. This resulted into fractionation of the bound WPC mixture into four different peaks. These peaks were named A, B, C and $\mathrm{D}$ according to their elution sequence and analyzed by SDS-PAGE. Elution of the last peak D was possible only after increasing the $\mathrm{pH}$ conditions along with elution strength. Figure 1 showed that peak A, which was obtained as a flow-through fraction, was a peak of glycomacropeptide (GMP). SDS-PAGE analysis, Figure 2, showed that Peak B was primarily BSA, peak $\mathrm{C}$ was a mixture of BLG and ALA, peak D was LPO. Further, fractionation of the remaining components 
of WPC was done by shallowing the gradient slope. For this, the $20 \mathrm{BV}$ linear gradient was modified to $26 \mathrm{BV}$. This modified shallow gradient resulted in the fractionation of the single peak $\mathrm{C}$ into two different peaks $\mathrm{C}_{1}$ and $\mathrm{C}_{2}$, as shown in Figure 1.

Application of a linear gradient for bigger diameter columns causes radial and axial deviation in elution strength of the mobile phase. Therefore, the linear gradient was transformed into a step gradient protocol. The elution strengths of gradient steps were estimated by correlating the conductivity (\% Elu-I) of the mobile phase with the elution strength of the corresponding peaks obtained in linear gradient process (Pedersen et al., 2003; Yamamoto et al., 1999; Yamamoto and Ishihara, 1999). The elution strength of the second gradient step was optimized to obtain resolution of peak $\mathrm{C}$ into individual protein peaks $\mathrm{C}_{1}$ and $\mathrm{C}_{2}$ in a single step. These peaks $\mathrm{C}_{1}$ and $\mathrm{C}_{2}$ were collected separately and analyzed by SDS-PAGE for the confirmation of protein components eluted as shown in Figure 2.

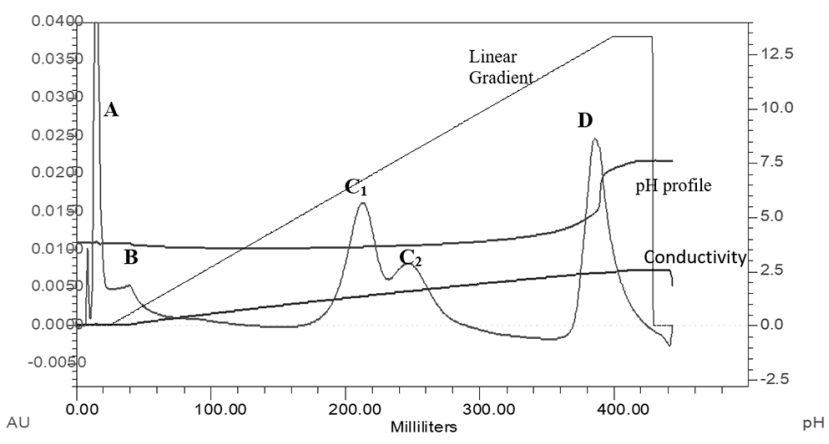

Figure 1. Chromatogram showing fractionation of whey [Sample injection: $0.5 \mathrm{~mL}\left(10 \mathrm{mg} \mathrm{mL}^{-1}\right)$, Flow rate: $38 \mathrm{~cm} \mathrm{~h}^{-1}$, and Elution: Linear gradient- 0 to $100 \%$ of $1 \mathrm{M} \mathrm{NaCl}$ in 26 bed volumes]

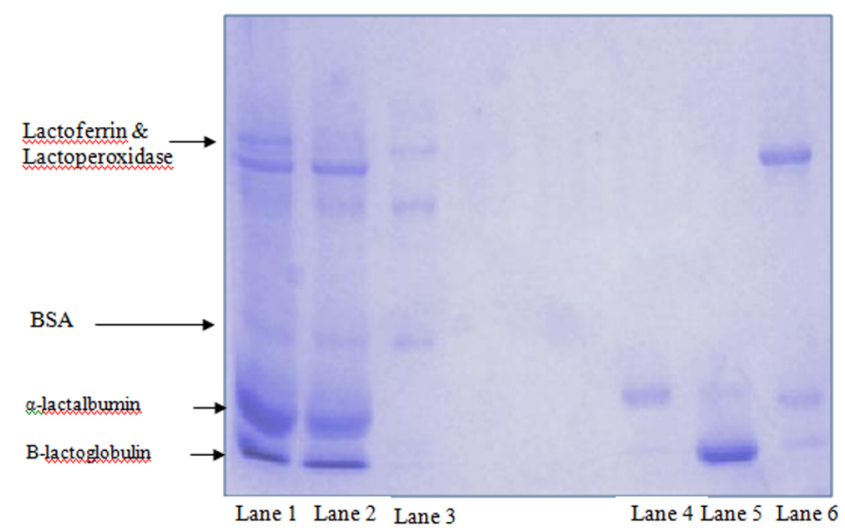

Figure 2. Non-reducing SDS-PAGE of whey protein fractionation using UNOsphere $\mathrm{S}$

[Lane 1-Loading whey sample, Lane 2- 2x diluted load sample, Lane 3- $0.5 \mathrm{M} \mathrm{NaCl}$ elution (Peak B- Majorly BSA), Lane 4. $0.75 \mathrm{M} \mathrm{NaCl}$ elution (peak C1- $\alpha$ lactalbumin) Lane 5 - $0.75 \mathrm{M} \mathrm{NaCl}$ elution (Peak C2$\beta$ lactoglobulin), Lane 6- 1.0 M NaCl eluted (Peak D- Lactoperoxidase)]
SDS-PAGE analysis showed that $\mathrm{C}_{1}$ was the peak of $\alpha$-lactalbumin and $\mathrm{C}_{2}$ was the protein $\beta$-lactoglobulin. Resolution of these two individual proteins in a single step was the requisite of the lab scale method for the study of the effect of scale-up strategy on separation performance. Exploiting the correlation of elution strength of protein peaks with composition of elution buffer, the optimized steps of the gradient elution protocol developed were as: first step: $0.5 \mathrm{M} \mathrm{NaCl}$ with a $\mathrm{pH}$ of 3.2 ; second step: elution in $0.75 \mathrm{M} \mathrm{NaCl}$ with slightly higher $\mathrm{pH}$ of 3.7 ; and third step elution in $1.0 \mathrm{M} \mathrm{NaCl}$ of $\mathrm{pH} 8$. The last elution step causes elution and regeneration of the column and makes it ready for the next cycle of operation. This modified step gradient process fractionates whey in to five different fractions, A, B, $\mathrm{C}_{1}, \mathrm{C}_{2}$ and $\mathrm{D}$ as shown in Figure 3. The densitometric analysis of the fractions obtained from the modified step gradient method showed that Peak A of GMP proteins was $91 \%$ pure with $89 \%$ recovery of the loaded amount; Fraction B was protein BSA with purity of $56 \%$ with recovery of $92.5 \%$ of the loaded amount; fraction C1 was ALA having purity of $97 \%$ with recovery of $80 \%$, fraction $\mathrm{C} 2$ was BLG having purity of $93 \%$ with recovery of $61 \%$, while fraction D of LPO was of purity $95 \%$ with recovery of $76 \%$.

\section{Evaluation of Lab Scale Performance: Variation of Resolution with Velocity}

The effect of flow velocity on the resolution of peaks $\mathrm{C}_{1}$ and $\mathrm{C}_{2}$ was studied by conducting bench scale trials in the $38-520 \mathrm{~cm} \mathrm{~h}^{-1}$ flow velocity range with the developed optimized protocol. Resolution of the two neighboring peaks $\mathrm{C}_{1}$ and $\mathrm{C}_{2}$ was determined by Equation (2) using the experimental elution time and peak variance data obtained from these trials (Meyer, 2004).

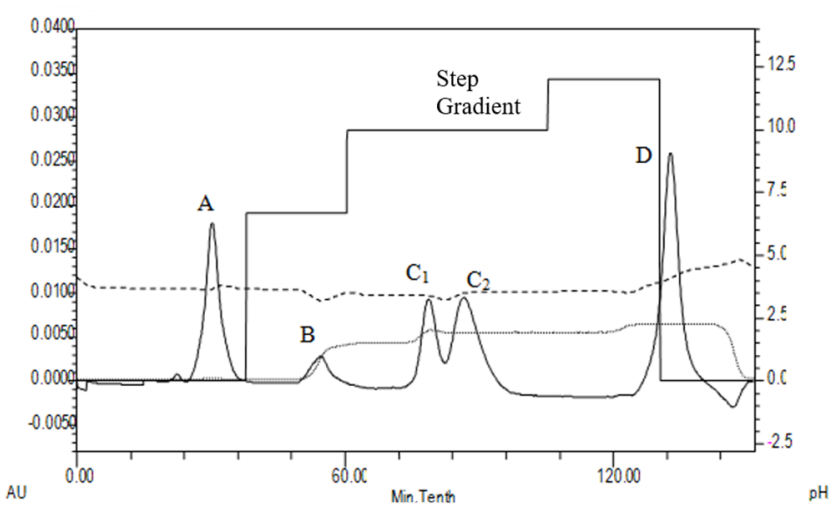

Figure 3. Chromatogram showing fractionation of whey into different fractions

[—-Absorbance $(280 \mathrm{~nm}), \longrightarrow$ Conductivity, _ - - - pH] 


$$
R_{S}=1.18 \frac{\left(t_{R C_{2}}-t_{R C_{1}}\right)}{\left(W_{1 / 2}\right)_{C_{1}}+\left(W_{1 / 2}\right)_{C_{2}}}
$$

The optimized bench scale process (Figure 3) produced a resolution of 1.6 between peaks $\mathrm{C}_{1}$ and $\mathrm{C}_{2}$ at a flow velocity of $38 \mathrm{~cm} \mathrm{~h}^{-1}$. High flow velocity showed a pronounced effect on resolution. It decreases nonlinearly with the increase of flow velocity. Variation of the resolution with the increase of flow velocities and number of plates for the lab scale column is shown in Figures $4 \mathrm{a}$ and $4 \mathrm{~b}$. Depending on the experimental data, the correlation of the variation of resolution for the peaks $\mathrm{C}_{1}$ and $\mathrm{C}_{2}$ with number of theoretical plates for the lab scale column was found to be:

$$
\left(R_{S}\right)_{1.0 \mathrm{~cm}}=0.0030 \mathrm{~N}+0.57
$$

The above correlation accounts for the variation of resolution with the number of plates as a function of flow velocity. It is used for the comparison or

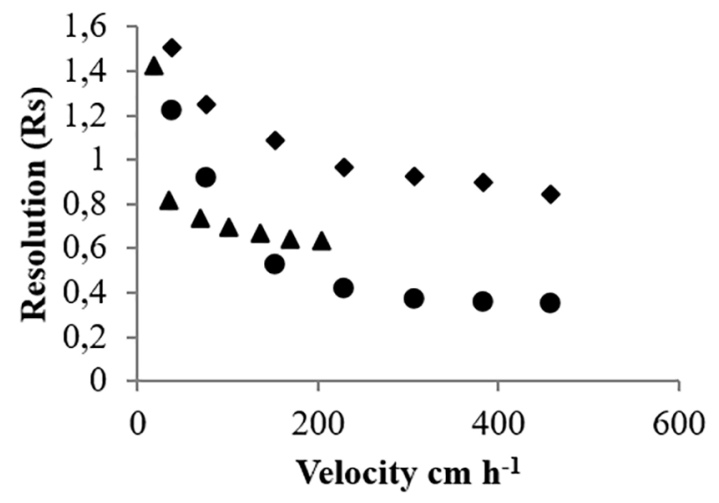

(a)

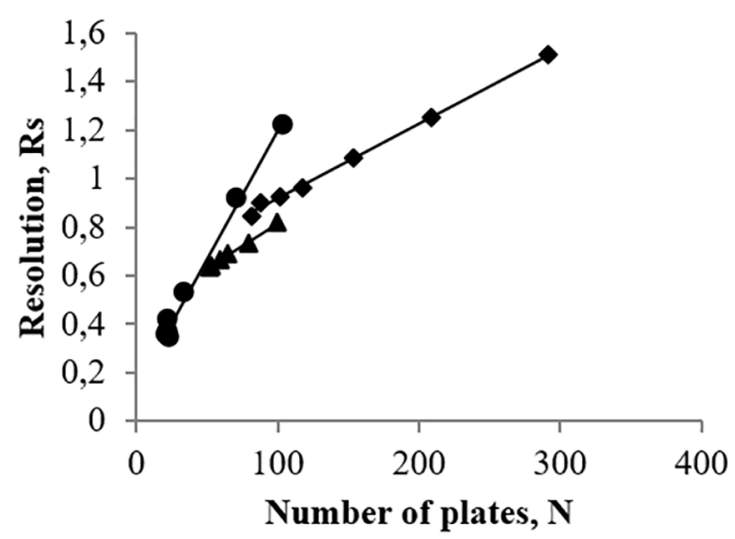

Figure 4. Comparison of resolution for lab and scaled columns for $\mathrm{H} / \mathrm{D}<19$ by the CV and CBVH methods a) Variation of resolution with velocity b) Variation of resolution with number of plates [ Lab scale $1.0 \mathrm{~cm} \times$ $19 \mathrm{~cm}=15 \mathrm{~mL}$ column $\left.\left(\mathrm{R}_{\mathrm{s}}=0.003 \mathrm{~N}+0.57, \mathrm{R}^{2}=0.99\right) \bullet C_{V,(H / D<19)}\right)$ scaleup in $1.5 \mathrm{~cm} \times 8.5 \mathrm{~cm}=15 \mathrm{~mL}$ column $\left(\mathrm{R}_{\mathrm{s}}=0.01 \mathrm{~N}+0.15, \mathrm{R}^{2}=0.99\right) \boldsymbol{\Delta}$ $C_{B V H .(H / D)<19}$ scale up in $1.5 \mathrm{~cm} \times 8.5 \mathrm{~cm}=15 \mathrm{~mL}$ column $\left(\mathrm{R}_{\mathrm{s}}=0.003 \mathrm{~N}+\right.$ $\left.\left.0.52, \mathrm{R}^{2}=0.99\right)\right]$ differentiation of the performance of the scaled column with the lab scale system.

\section{Scale-up Studies for the WPC Resolution System}

CONSTANT Velocity SCALE-UP: FOR $H / D<19\left(C_{V,(H / D<19)}\right)$

In this technique, scale-up trials were carried out over a range of flow velocities in lower height-large diameter $1.5 \mathrm{~cm} \times 8.5 \mathrm{~cm}$ and $2.5 \mathrm{~cm} \times 3.2 \mathrm{~cm}$ columns by keeping bed volume and the corresponding loading constant to that of the lab scale system. The flow rate required for the trials was estimated using the cross sectional area of the scaled column to keep the velocity range the same as that of the bench scale system. The detailed design and operation conditions used for this scale-up criterion are given in Table 3.

Separation performance was severely affected in the $2.5 \mathrm{~cm}$ diameter scaled column. It did not produce any kind of resolution between peaks $\mathrm{C}_{1}$ and $\mathrm{C}_{2}$, and both of these components were eluted as a single peak. This was due to the small bed height provided for the resolution of close components. The other $1.5 \mathrm{~cm}$ diameter scaled column produced a lower resolution of 0.53 of the same $\mathrm{C}_{1}$ and $\mathrm{C}_{2}$ peaks compared to 1.08 of the lab scale trial at $76 \mathrm{~cm} \mathrm{~h}^{-1}$. Comparison of preparative chromatograms of WPC resolution performed at $76 \mathrm{~cm} \mathrm{~h}^{-1}$ velocity for the lab scale $1.0 \mathrm{~cm}$ column and the bigger diameter $1.5 \mathrm{~cm}$ column scaled by the $C_{V, H / D<19}$ method is shown in Figure 5. Similar results of lower resolution than bench scale were obtained for the trials conducted in the range of 38$520 \mathrm{~cm} \mathrm{~h}^{-1}$ velocities for the $1.5 \mathrm{~cm}$ diameter column.

To find out the reason behind this loss, the variation of the resolution with the number of plates and flow velocity for the scaled $1.5 \mathrm{~cm}$ diameter column was compared with lab scale performance as shown in Figures $4 \mathrm{a}$ and $4 \mathrm{~b}$. The low resolution in the scaled $1.5 \mathrm{~cm}$ diameter column was due to the lower number of stages provided by its shorter bed height. Also, the trend of variation of resolution with number of plates of this low height-larger diameter scaled column was different than the lab scale, when operated by the constant velocity approach. This can be confirmed from the dissimilar trend of variation of resolution with number of stages for the scaled $1.5 \mathrm{~cm}$ column defined by Equation (4). The slope of correlation (4) is different compared to the lab scale trend as predicted by correlation (3).

$$
\left(R_{S}\right)_{1.5 c m, C_{V}, H / D<19}=0.010 \quad N+0.15
$$

This indicates that the lab level separation performance is affected if it is scaled by the constant 


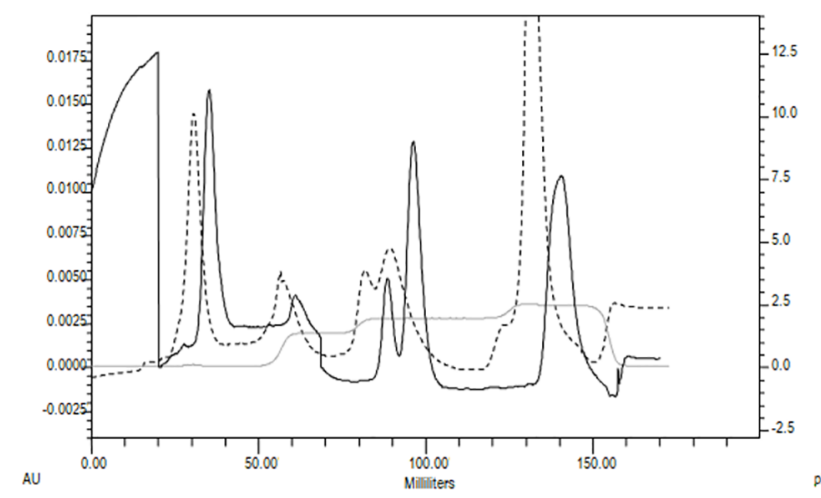

Figure 5. Comparison of the variation of whey resolution of the lab scale system with the number of plates by the $\mathrm{C}_{\mathrm{v}(\mathrm{H} / \mathrm{D}<19)}$ scale up method for 1.0 and $1.5 \mathrm{~cm}$ diameter columns

[_Lab Resolution, _ _ _ Scaled system resolution;

Conductivity]

velocity technique in larger diameter columns with lower $\mathrm{H} / \mathrm{D}$ ratio than that of the bench scale system. Constant BVH sCALE-UP: BY H/D <19 [ $\left.C_{B V H,(H / D)<19}\right]$

In the constant $\mathrm{C}_{\mathrm{BVH}(\mathrm{H} / \mathrm{D}<19)}$ scale up approach, flow velocities or flow rates were modified according to the bed height of the scaled column to keep the retention time the same as that of the bench scale system. Scaleup trials in a bigger $2.5 \mathrm{~cm}$ diameter column did not reproduce the lab scale performance. However, a little resolution of peaks $\mathrm{C}_{1}$ and $\mathrm{C}_{2}$ was observed as compared to no resolution of the $\mathrm{C}_{\mathrm{V},(\mathrm{H} / \mathrm{D}<19)}$ strategy. This was also because of insufficient height available for resolution in the scaled $2.5 \mathrm{~cm}$ diameter column. These conditions were substantially improved when the column height was increased up to $8.5 \mathrm{~cm}$ in the $1.5 \mathrm{~cm}$ diameter column. It reproduced the resolution performance of the lab scale column. Overlay preparative chromatograms of the lab scale $(1.0 \times 19$ $\mathrm{cm}$ column $)$ run and the scaled $(1.5 \times 8.5 \mathrm{~cm}$ column $)$ trial by the $\mathrm{C}_{\mathrm{BVH},(\mathrm{H} / \mathrm{D}<19)}$ strategy at a flow velocity of 76 $\mathrm{cm} \mathrm{h}^{-1}$ are shown in Figure 6. It can be visualized from Figure 6 that the $\mathrm{C}_{\mathrm{BVH},(\mathrm{H} / \mathrm{D}<19)}$ approach reproduces the bench scale trend of resolution of peaks $\mathrm{C}_{1}$ and $\mathrm{C}_{2}$. This can also be confirmed from the variation of resolution with the number of stages correlated by Equation (5).

$$
\left(R_{S}\right)_{1.5 \mathrm{~cm}, C_{B V H}(H / D)<19}=0.003 N+0.52
$$

The lower value of the intercept in Equation (5) than for the bench scale indicates the limit of maximum possible resolution. This was due to lower bed height and number of plates in the scaled column system. However, the identical slope of Equation (5) of $1.5 \mathrm{~cm} \times 8.5 \mathrm{~cm}$ column scaled by $\mathrm{C}_{\mathrm{BVH}, \mathrm{H} / \mathrm{D}<19)}$ as that of Equation (3) of the lab scale indicated similar band movement or zone broadening

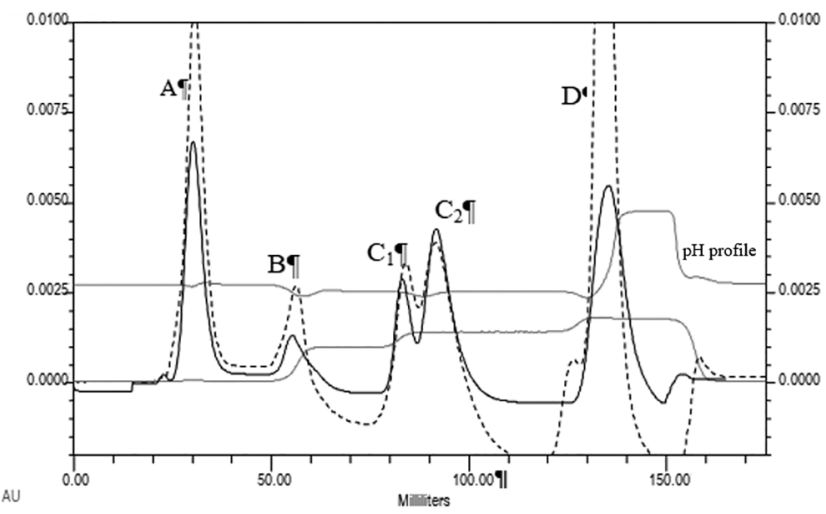

Figure 6. Comparison of whey resolution in 1.0 and $1.5 \mathrm{~cm}$ diameter same volume columns by the $\left(\mathrm{C}_{\mathrm{BVH}}\right)_{(\mathrm{H} / \mathrm{D}<19}$ scaling up strategy

[_Lab Resolution, _ _ _ Scaled system resolution;

Conductivity]

variation with flow velocity. This means that $\mathrm{C}_{\mathrm{BVH}}$ reproduces hydrodynamic conditions similar to those of the lab scale column even if the scaled height was lower than lab-scale. Thus, $\mathrm{C}_{\mathrm{BVH}}$ is an efficient scale up strategy for radial scale up, but not for the cases where the scaled bed height is substantially lower $(\mathrm{H} / \mathrm{D}<2$ for $2.5 \mathrm{~cm}$ dia. column) compared to the bench scale system. In such cases, scale-up may under-produce the lab performance due to the lower number of stages. Therefore, for the systems where final purity of product is an essential attribute, during scaling of the process it is recommended to find the optimum height for separation at the bench or pilot scale.

CONSTANT VELOCITY SCALE UP: BY H/D=19, $C_{V,(H / D) L=(H / D) S}$

Overcoming the inadequacy of the earlier constant velocity scale-up was tried by keeping the H/D ratio and velocity the same as that of bench scale. This confirms the effect of aspect ratio on scale-up strategies while scaling. Therefore, in this concept, the scaled height of $1.5 \mathrm{~cm}$ and $2.5 \mathrm{~cm}$ diameter columns was larger than bench scale to maintain the bench scale $\mathrm{H} / \mathrm{D}$ ratio. Loading was done in accordance with Equation (1) for these larger diameter columns. Based on the constant velocity concept, the operating parameters were estimated and bed height was as per the $(H / D)_{L}=(H / D)_{S}$ concept. As the flow velocity in the scaled column was constant relative to that of the lab scale column, the processing time of the larger volume scaled column is higher than the lab level. Overlaid preparative chromatograms of Figure 7 shows the effect of the $\mathrm{C}_{V,(\mathrm{H} / \mathrm{D}) \mathrm{L}=(\mathrm{H} / \mathrm{D}) \mathrm{S}}$ strategy on resolution of the $\mathrm{C}_{1}$ and $\mathrm{C}_{2}$ peaks in the scaled $1.5 \mathrm{~cm}$ column in comparison with the lab scale $1.0 \mathrm{~cm}$ column. Such overlaid comparison of the scaled $2.5 \mathrm{~cm} \times 47.5 \mathrm{~cm}$ column was not possible due to the substantially larger run time than lab scale. 


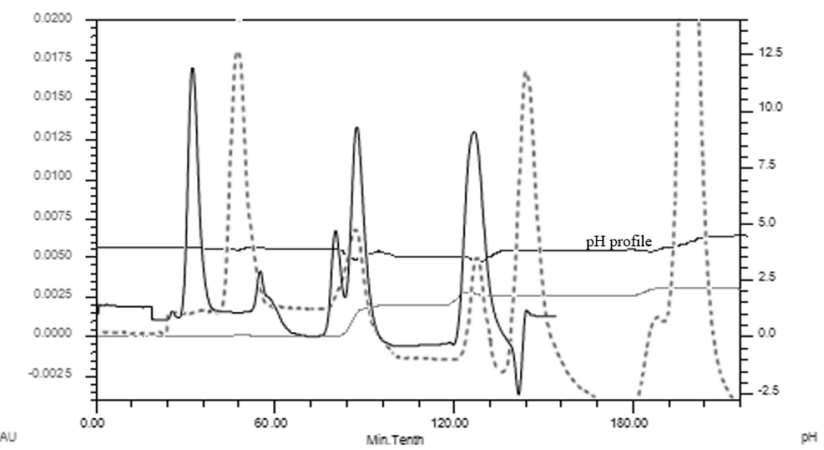

Figure 7. Comparison of whey resolution in the lab scale $1.0 \mathrm{~cm}$ column and the $1.5 \mathrm{~cm}$ diameter column scaled by the $\mathrm{C}_{\mathrm{v}(\mathrm{H} / \mathrm{D}=19)}$ approach

[ـLab Resolution, - - - Scaled system resolution;

Conductivity]

The comparison showed higher resolution in the scaled $1.5 \mathrm{~cm}$ column than bench scale in the range of 78 to $152 \mathrm{~cm} \mathrm{~h}^{-1}$. This was due to the higher number of stages provided by the larger $28.5 \mathrm{~cm}$ height, which was 1.5 fold larger than the $8.5 \mathrm{~cm}$ height used for the earlier $\mathrm{C}_{\mathrm{V},(\mathrm{H} / \mathrm{D}<19)}$ strategy (Figure 8a).

However, the trend of variation of resolution with velocity was similar to that of bench scale. Therefore, the slope of the hydrodynamic performance predicted by Equation (6) of the scaled $1.5 \mathrm{~cm}$ diameter column for $\mathrm{C}_{V,(\mathrm{HDDL}=(\mathrm{HD}) \mathrm{S}}$ conditions is identical to that of Equation (3) of the lab scale system. This is not the case with the scaled column of $2.5 \mathrm{~cm}$ diameter, mainly due to the 2.5 -fold larger height and longer retention time relative to the lab scale. This means that the $\mathrm{C}_{\mathrm{V}}$ scale-up approach may reproduce the lab hydrodynamic performance for scaled system up to 1.5 times larger height scaled columns than lab scale; beyond that substantial deviation was observed.

$$
\left(R_{S}\right)_{1.5 \mathrm{~cm}, C_{V},(H / D) L=(H / D) S}=0.003 N+0.54
$$

\section{CONSTANT BVH SCALE UP: FOR $H / D=19, C_{B V H,(H D) L=(H / D) S}$}

The design and operating conditions reported in Table 3 were used to conduct the trial by the $C_{B V H \text {. }}$ $(H D) L=(H D) S$ approach. A column height of $28.5 \mathrm{~cm}$ was used to maintain the H/D of 19 to that of bench scale column. Overlaid preparative chromatogram for the trial conducted with the $C_{B V H,(H D D L=(H D) S}$ strategy in the scaled $2.5 \mathrm{~cm}$ column in comparison with the lab scale $1.0 \mathrm{~cm}$ column is shown in Figure 9. Comparison showed that the $C_{B V H,(H D D L=(H D D) S}$ strategy reproduces the lab scale resolution of peaks $\mathrm{C}_{1}$ and $\mathrm{C}_{2}$. Similar performance was observed for the trials conducted in a $1.5 \mathrm{~cm}$ diameter column. The recovery and purity of BLG, ALA and other protein components obtained from the scaled trials by $\mathrm{C}_{\mathrm{BVH},(\mathrm{HD}) \mathrm{L}=(\mathrm{HD}) \mathrm{S}}$ in both the 1.5 and $2.5 \mathrm{~cm}$ diameter columns were also in accordance with the lab scale operation. Again to check this

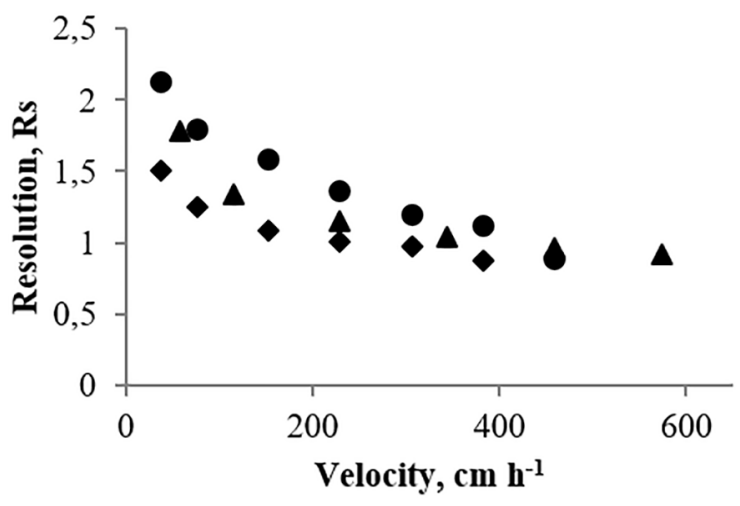

(a)

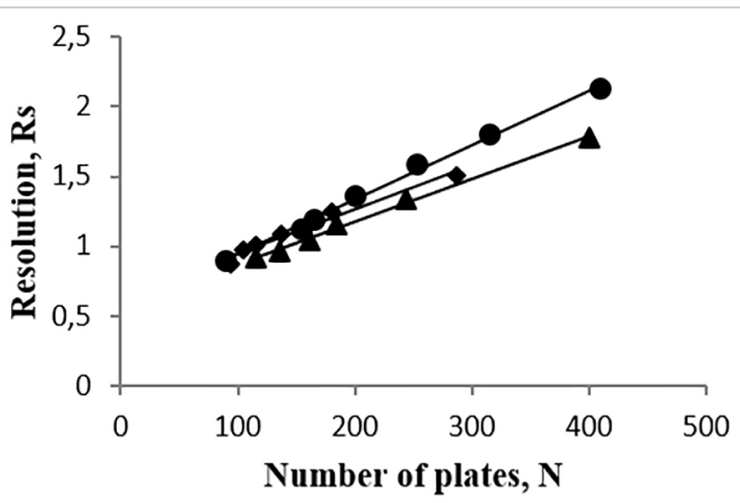

(b)

Figure 8. Comparison of resolution by constant H/D ratio scale up for the bench scale $1.0 \mathrm{~cm}$ diameter and scaled 1.5 and $2.5 \mathrm{~cm}$ diameter columns a) Variation of resolution with velocity b) Variation of resolution with number of plates

[ Lab scale $1.0 \times 19 \mathrm{~cm}=15 \mathrm{~mL}$ column, $\mathrm{Rs}=0.003 \mathrm{~N}+0.5, \mathrm{R}^{2}=0.99$, - Scaled trial for $\mathrm{C}_{\mathrm{BVH}}$ with $(\mathrm{H} / \mathrm{D}) \mathrm{L}=(\mathrm{H} / \mathrm{D}) \mathrm{S}$, in $1.5 \mathrm{~cm} \times 28 \mathrm{~cm}=50 \mathrm{~mL}$, $\mathrm{Rs}=0.003 \mathrm{~N}+0.54, \mathrm{R}^{2}=0.99 \boldsymbol{\Delta}$ scaled trial for H/D-ratio $(\mathrm{H} / \mathrm{D}) \mathrm{L}=(\mathrm{H} / \mathrm{D}) \mathrm{S}$ using the CBVH approach in $1.5 \times 28 \mathrm{~cm}=50 \mathrm{~mL}, \mathrm{Rs}=0.003 \mathrm{~N}+0.6$, $\left.\mathrm{R}^{2}=0.99\right)$

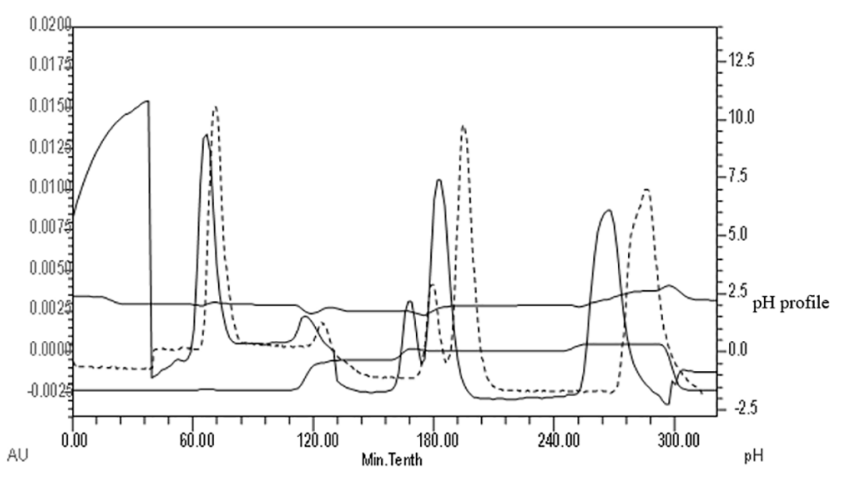

Figure 9. Comparison of whey resolution in lab scale $1.0 \mathrm{~cm}$ and scaled 2.5 $\mathrm{cm}$ diameter columns scaled by the $\left(\mathrm{C}_{\mathrm{BVH}}\right)\left(_{\mathrm{H} / \mathrm{D}<19}\right.$ approach

[_Lab Resolution, _ _ _ Scaled system resolution; Conductivity]

reproducibility in terms of hydrodynamic performance, variation of resolution with velocity and number of plates was determined and compared in Figure 8b with lab performance. An identical correlation (Equation 7) to the bench scale system was obtained for both $2.5 \mathrm{~cm}$ 
and 1.5 diameter scaled columns for the $C_{B V H,(H / D) L=(H / D)}$ ${ }_{s}$ scale-up strategy.

$$
\left(R_{S}\right)_{1.5 \& 2.5 \mathrm{~cm}, C_{B V H,(H / D) L}=(H / D) S}=0.003 N+0.57
$$

This identical slope and intercept of Equation (7) to that of bench scale Equation (3) confirmed that the $\mathrm{C}_{\mathrm{BVH}}$ strategy reproduces the hydrodynamic or resolution performance of the lab scale system. Trials for bench scale and both the $C_{B V H,(H / D) L=(H / D) S}$ and $\mathrm{C}_{V,(\mathrm{H} / \mathrm{D}) \mathrm{L}=(\mathrm{H} / \mathrm{D}) \mathrm{S}}$ strategies showed a similar trend of loss of resolution with flow velocity. Because of the accessibility characteristic of Unosphere S, rapid loss of resolution was observed beyond a velocity of $152 \mathrm{~cm} \mathrm{~h}^{-1}$ (Ingle and Lali, 2017). As a result of this, UNOsphere provides maximum intraparticle area for resolution for velocities lower than $152 \mathrm{~cm} \mathrm{~h}^{-1}$, beyond which loss of pore area accessibility affects hydrodynamic performance and reduces resolution. Therefore, a plateau of resolution values was observed in the range of 152 to $229 \mathrm{~cm} \mathrm{~h}^{-1}$ flow velocities.

The experimental outcome indicated that the unnecessary prediction of taller height to keep the $\mathrm{H} / \mathrm{D}$ ratio the same as that of lab scale system causes extra resin volume and sometime higher resolution (Figures 6 and 8) at corresponding flow conditions. Such conditions will be responsible for the under utilization of resin volume during scale-up. Therefore, radial scale-up by keeping the height the same as that of the bench scale system is successful for the scale-up of the equilibrium type purification systems. This involves a number of optimization trial-error experiments at the lab scale and pilot scale level to establish the desired purification height. Another way is the prediction of the optimum height by establishing the empirical correlations by conducting experiments at the bench scale. Therefore, in the present work an empirical equation was devised for the prediction of optimum height for whey protein resolution.

\section{Equation for the Prediction of Scale-up Performance of WPC Resolution System}

The equation for the variation of resolution in terms of number of plates and separation factor is as follows (Meyer, 2004):

$$
R_{S}=\frac{1}{4}(\alpha-1) \sqrt{N}\left[\frac{k_{1}}{1+K^{\prime}}\right]
$$

where $\mathrm{N}$ is the number of theoretical stages, $\mathrm{k}_{1}=$ capacity factor with respect to peak $\mathrm{C}_{1}, \mathrm{k}_{2}$ is the capacity factor with respect to peak $\mathrm{C}_{2}, \mathrm{~K}^{\prime}=\left(\mathrm{k}_{1}+\mathrm{k}_{2}\right) / 2$ and $\alpha$ is the separation factor $\left(\mathrm{k}_{2} / \mathrm{k}_{1}\right)$. Equation (8) signifies the pronounced effect of number of plates and retention time on resolution. But it can be observed from the above two scale-up methods that the number of plate is a height dependent parameter. It changes with column height even when zone broadening or hydrodynamic performance is reproduced properly in the scaled column. To account for this phenomenon, the present investigation modifies the number of plates term by using the height independent HETP with the correlation reported by Rathore and Velayudhan, (2002).

$$
\frac{1}{N}=\left(\frac{H_{T}}{u}\right) \cdot \frac{1}{t_{R}}
$$

where $t_{R}$ is the retention time of solute or first central moment and $\mathrm{H}_{\mathrm{T}} / \mathrm{u}$ is the equation correlating the relationship of the HETP vs. velocity (u) plot. Thus, the equation of resolution can be expressed in terms of operating parameter and HETP as:

$$
R_{s}=\frac{1}{4}(\alpha-1) \sqrt{\frac{V}{Q}}\left(\frac{u}{H_{T}}\right)\left[\frac{k_{1}}{1+K^{\prime}}\right]
$$

where $\mathrm{V}$ is the volume of the column and $\mathrm{Q}$ is the flow rate. It can be observed from Equation (10) that the resolution factor can now be predicted if the variation of HETP with flow velocity is known. To find out the HETP and its dependence on flow velocity in the process of separation of WPC components, the variation of the HETP as a function of flow velocity was determined. Therefore, the HETP data obtained for the bench scale $(1.0 \mathrm{~cm}$ diameter) separation and the scaled trials by the $\mathrm{C}_{\mathrm{V}}$ and $\mathrm{C}_{\mathrm{BVH}}$ strategies for the

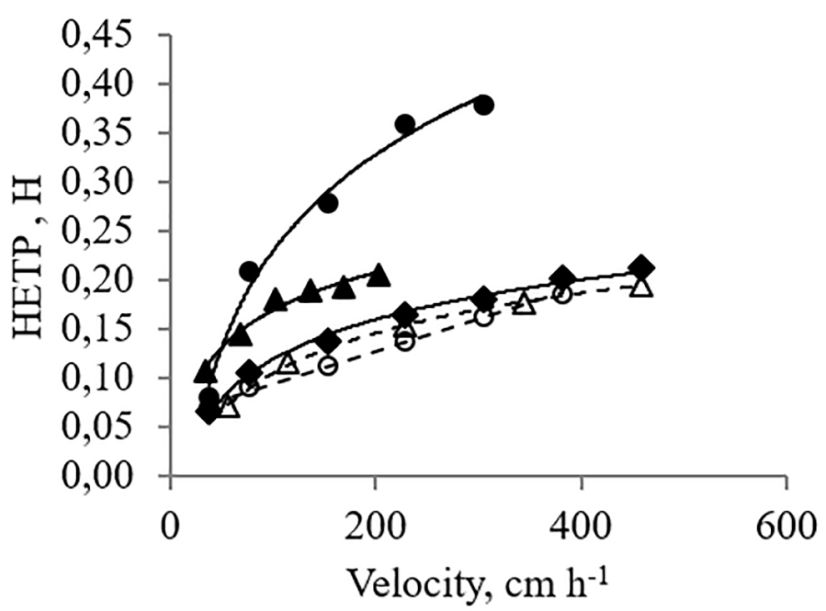

Figure 10: Variation of HETP with velocity for 1.0 and $1.5 \mathrm{~cm}$ columns [ Lab scale $(1.0 \times 19 \mathrm{~cm}=15 \mathrm{~mL})$ column, $\mathrm{H}=0.058 \mathrm{Ln}(\mathrm{u})-0.15$ with $\mathrm{R}^{2}=0.99, \bullet \mathbf{C}_{\mathbf{V}, \mathbf{H} / \mathbf{D})<19}$ in $1.5 \mathrm{~cm} \times 8.5 \mathrm{~cm}=15 \mathrm{~mL}$ column, $\mathrm{H}=0.142$ $\mathrm{Ln}(\mathrm{u})-0.42$ with $\mathrm{R}^{2}=0.98, \boldsymbol{\Delta} \mathbf{C}_{\mathbf{B V H},(\mathbf{H} / \mathbf{D})<19}$ in $1.5 \times 8.5 \mathrm{~cm}=15 \mathrm{~mL}$ column, $\mathrm{H}=0.055 \mathrm{Ln}(\mathrm{u})-0.1$ with $\mathrm{R}^{2}=0.99, \circ \mathrm{C}_{\mathbf{V},(\mathbf{H} / \mathbf{D}) \mathrm{L}=(\mathbf{H} / \mathbf{D}) \mathrm{s}}$ in $1.5 \times 28 \mathrm{~cm}=50 \mathrm{~mL}$ column, $\mathrm{H}=0.00033(\mathrm{u})+0.062, \mathrm{R}^{2}=0.99, \Delta \mathbf{C}_{\mathrm{BVH},(\mathbf{H} / \mathrm{D}) \mathrm{L}=(\mathbf{H} / \mathbf{D}) \mathrm{S}}$ in $1.5 \times 28$ $\mathrm{cm}=50 \mathrm{~mL}$ column, $\mathrm{H}=0.058 \mathrm{Ln}(\mathrm{u})-0.16$ with $\left.\mathrm{R}^{2}=0.99\right]$ 
$1.5 \mathrm{~cm}$ diameter column were studied as shown in Figure 10.

The constant velocity scale-up strategy showed HETP-velocity relationships (linear, $\mathrm{H}=0.00033 \mathrm{u}$ for $\mathrm{C}_{\mathrm{V}, \mathrm{H} / \mathrm{D}}<19$ and logarithmic, $\mathrm{H}=0.142 \mathrm{Ln} \mathrm{u}$ for $\mathrm{C}_{\mathrm{v}}$, $(\mathrm{H} / \mathrm{D}) \mathrm{L}=(\mathrm{H} / \mathrm{D}) \mathrm{S}$ ) which are completely different from the lab scale system performance. However, $\mathrm{C}_{\mathrm{BVH}}$ produces identical logarithmic variation of HETP with velocity for both $H / D<19$ and $(H / D)_{L}=(H / D)_{H}$ criteria to that of lab scale performance as defined by Equation (11).

$$
H_{T}=0.0584 \ln (u)-0.1493
$$

Equation (11) closely correlates the variation of HETP with velocity over the range of design and operating conditions if the scale up criterion is $\mathrm{C}_{\mathrm{BVH}}$. Therefore, by developing such HETP-velocity relationship at the lab scale, it is possible to predict the optimum height for the scaled condition by simultaneous solution of Equations (10) and (11).

\section{Validation of the Modified Resolution Equation by Comparison with Experimental Results}

During scale-up, productivity decides the velocity and column dimensions. Only void volume and retention time changes in the scaled column. But by keeping constant loading per unit volume, the same elution conditions with packing of the same resin, a similar distribution of solute components between solid and liquid phases occurred. This reproduces the capacity factor and separation factor of the bench scale system. Depending on the above conditions, the resolution of peak $\mathrm{C}_{1}$ and $\mathrm{C}_{2}$ was predicted by

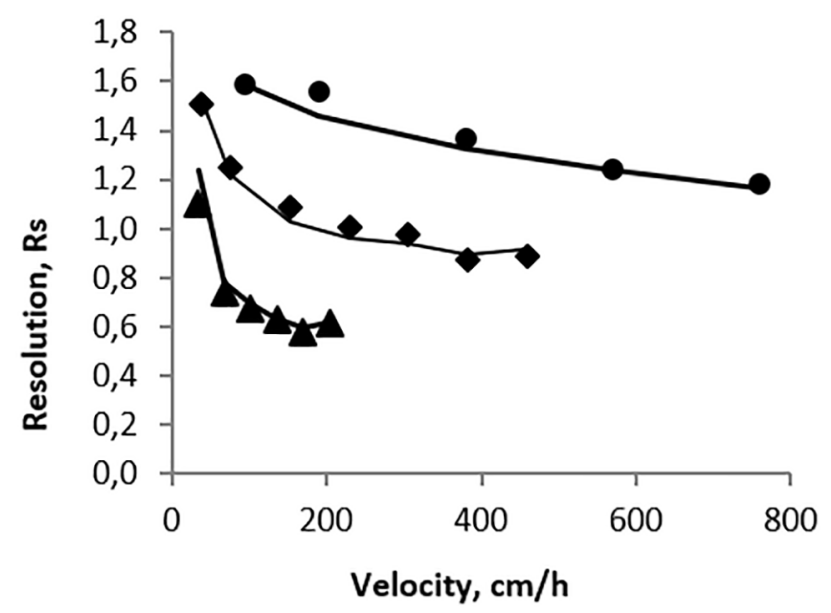

Figure 11: Comparison of the variation of experimental resolution with predicted values of the resolution with flow velocity in different size columns [ Experimental resolution values lab scale $1.0 \mathrm{~cm} \times$ $19 \mathrm{~cm}$ column $\Delta$ Experimental resolution $1.5 \mathrm{~cm} \times 8.5 \mathrm{~cm}(\mathrm{H} / \mathrm{D}<19) \bullet$ Experimental resolution in $2.5 \mathrm{~cm} \times 47.5 \mathrm{~cm}(\mathrm{H} / \mathrm{D}=19)$

[The solid curves represent the predictions of the resolution equation] simultaneous solution of Equation (10) and (11). Figure 11 shows the comparison of experimental data points obtained for the bench scale $1.0 \mathrm{~cm} \times 19 \mathrm{~cm}$ column, the scaled $1.5 \times 8.5 \mathrm{~cm}$ (lower $\mathrm{H} / \mathrm{D}$ ratio than lab scale $)$ and $2.5 \mathrm{~cm} \times 47.5 \mathrm{~cm}(\mathrm{H} / \mathrm{D}$ ratio $=\mathrm{H} / \mathrm{D}$ bench scale) columns with the values predicted for resolution by Equation (10). The close agreement of the model equation curves and experimental data points of Figure 11 indicated that the equation developed predicts resolution in accordance with the experimental values for different aspect ratio scaled columns.

\section{CONCLUSIONS}

This study presented the development of a onestep purification process for the resolution of various proteins of whey using UNOsphere S. The study also presented scale-up of this whey separation system by various scale-up strategies. This is done by conduction of scale-up trials at various scales and generation of scale-up data for different scale-up approaches. The comparison of separation performance of scaled experiments with lab level over a wide range of operating conditions was done by HETP-velocity and resolution-velocity relationships. The scale-up experiments for the present separation process showed that $\mathrm{C}_{\mathrm{BVH}}$ is an accurate method for the scale-up of equilibrium type purification systems due to recreation of the hydrodynamic conditions of the bench level irrespective of design parameters of the scaled system. The work also highlighted the importance of optimum bed height in the scaled column for the reproduction of the lab level separation performance. Therefore, the work suggests prediction of the optimum height by experimentation or by developing empirical correlations for the desired resolution or separation before scaling-up the purification system. The work presented a handy empirical equation on the basis of lab level HETP-velocity correlations to predict performance over a range of scale-up conditions. The developed correlation (Equation (10)) can also be applied for the prediction of the height of the scaled column to achieve the desired or lab scale resolution. Moreover, the work showed that scale-up of a specific equilibrium separation system is more accurate and flexible by developing empirical correlations based on lab scale data. The work provides the details of the effects of scale-up factors on the reproduction of separation performance, providing the guidelines for the selection of a suitable strategy for the scale-up of a chromatographic purification system. 


\section{REFERENCES}

Baldasso, C., Barros, T.C. and Isabel, C.T., Concentration and purification of whey proteins by ultrafiltration. Desalination, 278 381-386 (2011).

Charm, S.E. and Matteo, C.C., Scale-Up of protein isolation. Methods Enzymol., 22 476-478 (1971).

Doultani, S., Turhan, K.N. and Etzel, M.R., Fractionation of proteins from whey using cation exchange chromatography. Process Biochem, 39 1737-1743 (2004).

Doultani, S., Turhan, K.N. and Etzel, M.R., Whey protein isolate and glyco-macropeptide recovery from whey using ion exchange chromatography. J. Food Sci., 68 1389-1395 (2003).

Faraji, N., Zhang, Y. Ray, A.K., Determination of adsorption isotherm patterns for minor whey proteins by gradient elution preparative liquid chromatography. Journal of Chromatography A., 1412 67-74 (2015).

Fee, C.J. and Chand, A., Capture of lactoferrin and lactoperoxidase from raw whole milk by cation exchange chromatography. Sep. Purif. Technol., 48 143-149 (2006).

Gerberding, S.J. and Byers, C.H., Preparative ionexchange chromatography of proteins from dairy whey. Journal of Chromatography A, 808 141-151 (1998).

Goodall, S., Grandison, A.S., Jauregi, P.J. and Price, J., Selective separation of the major whey proteins using ion exchange membranes. J. Dairy Sci., 91, 1-10(2008).

Hagel, L., Jagschies, G., Sofer G. (second ed). Handbook of Process Chromatography- Separation Technologies, Academic Press, New York, NY, pp. 86-122 (2008).

Hann, R., Schulz, P.M., Schaupp, C. and Jungbauer, A., Bovine whey fractionation based on cation -exchange chromatography. Journal of Chromatography A, 795 277-287 (1998).

Heuer, C., Hugo, P. and Mann, G. Seidel-Morgenstern, A., Scale up in preparative chromatography. Journal of Chromatography A 752 19-29 (1996).

Hunter, A. K., and Carta, G., Protein adsorption on novel acrylamido-based polymeric ion-exchangers II. Adsorption rates and column behavior. Journal of Chromatography A, 897 81-97 (2000).

Ingle,U.M., andLali,A.M., Significance ofPorosity and Pore Accessibility for the Selection of Ion Exchange Adsorbents for Chromatographic Purification of Macromolecules. Acta Chromatographica, 29(1) 5-24 (2017) DOI: 10.1556/1326.2017.29.1.01
Ishihara, T., Kadoya, T. and Yamamoto, S., Application of a chromatography model with linear gradient elution experimental data to the rapid scale-up in ion-exchange process chromatography of proteins. Journal of Chromatography A, 1162 34-40 (2007).

Jansson, J-C. and Jonsson, J.A., Introduction to chromatography, in: De-Janson, J., Ryden, L. (Ed.), Protein purifications, Principles-High Resolution Methods and Applications. VCH Publishers, New York, pp.107-748 (1989).

Kirstiansen, K.R., Otte, J., Ipsen, R. and Qvist, K.B., Large-scale preparation of $\beta$-lactoglobulin A and $B$ by ultrafiltration and ion exchange chromatography. Int. Dairy Journal, 8,113-118 (1998).

Laemmli, U.K., Cleavage of structural proteins during the assembly of the heat of bacterophagT4. Nature, 227, 680- 685 (1970).

Levison, P.R., Badger, S.E., Toome, D.W., Koscielny, M.L., Lane, L. and Butts, E.T., Economic considerations important in the scale-up of an ovalbumin separation from hen egg-white on the anion exchange cellulose DE92. Journal of Chromatography A, 590 49-58 (1992).

Lightfoot, E.N., Speeding the Design of Bioseparations: A Heuristic Approach to Engineering Design. Ind. Eng. Chem. Res. 38 3628-3634 (1999).

Meyer, V.R., Practical High-Performance Liquid Chromatography, (Eds.), John Wiley \& Sons, New York (2004).

Mollerup, J.M., Hansen, T.B., Kidal, S., Sejergaard, L. and Staby, A., Development, modeling, optimisation and scale-up of chromatographic purification of a therapeutic protein. Fluid Phase Equilibria., 161 133-139 (2007).

Moscariello, J. Purdom, G. Coffman, J. Root, T.W. and Lightfoot, E.N., Characterizing the performance of industrial-scale columns. Journal of Chromatography A, 908 131-141 (2001).

Pearce, R.J., Thermal separation of beta-lactoblobulin and alpha-lactalbumin in bovine cheddar cheese whey. J. Dairy Sci. Technol., 15 133-22 (1983).

Pedersen, L., Mollerup, J., Hansen, E. and Jungbauer, A., Whey proteins as a model system for chromatographic separation of proteins. Journal of Chromatography B, 790 161-173 (2003).

Rathore, A.S. and Velayudhan, A., An overview of scale-up in preparative chromatography, in: Rathore, A.S. and Velayudhan A. (Eds.), Scale-Up and Optimization in Preparative Chromatography, Principles and Biopharmaceutical applications, Marcel Dekker, New York, pp. 1-32 (2002). 
Roger, L., Maubois, J.L., Brule, B. and Piot, M., Processs for obtaining an ALA enriched product from whey and uses thereof. US Patent No. 4485040, USA (1984).

Santos, M.J., Teixeira, J.A., Rodrigues, L.R., Fractionation of the major whey proteins and isolation of $b$-Lactoglobulin variants by anion exchange chromatography. Sep. Purif. Technol., 90 133-139 (2012).

Saufi, S. M. and Fee, C.J., Recovery of lactoferrin from whey using cross-flow cation exchange mixed matrix membrane chromatography. Separation and Purification Technology, 77 68-75 (2011).

Shanagar, J., Purification of a synthetic oligonucleotide by anion exchange chromatography: Method optimisation and scale-up. J. Biochem. Biophys. Methods, 64 216-225 (2005).

Uchida, T., Shimatani, M., Mitsuhanshi, T. and Koutake, M., Process for preparing a fraction having a high content of alpha-lactalbumin from whey and nutritional compositions containing such fractions. US Patent No. 5,503,864, USA (1996).
Vorauer, K., Skias, M., Trkola,A., Schulz, P., Jungbauer A.J.; Scale-up of recombinant protein purification by hydrophobic interaction chromatography; Journal of Chromatography A, 625: 33-39 (1992).

Voswinkel, L. and Kulozik, U., Fractionation of whey proteins by means of membrane adsorption chromatography. Procedia Food Science, 1 900907 (2011).

Wankat, P.C. and Koo, Y.M., Scaling Rules for Isocratic Elution Chromatography. AIChE J., 34 1006-1019 (1988).

Wilhelm,A.W. and Riba, J.P., Scale up and optimization in production liquid chromatography. Journal of Chromatography A, 484 211-223 (1989).

Yamamoto, S., Watler, P.K. and Feng, D. Kaltenbrunner, O., Characterization of unstable ion exchange chromatographic separation of proteins. Journal of Chromatography A, 852 37-41 (1999).

Yamamoto, S. and Ishihara, T., Ion-exchange chromatography of proteins near the isoelectric points. Journal of Chromatography A, 852 31-36 (1999). 